\title{
Costs, cobenefits, and community responses to REDD+: a case study from Nepal
}

\author{
Bishnu P. Sharma $^{1}, \underline{\text { Priya Shyamsundar }}^{2,3}$, Mani Nepal $^{2}, \underline{\text { Subhrendu K. Pattanayak }}^{2,4}$ and Bhaskar S. Karky ${ }^{5}$
}

\begin{abstract}
We examine the role of subnational institutions in carbon sequestration and assess whether community forest user groups can meet both existing forest needs and international carbon demand. By conducting a qualitative evaluation of a pilot program in Nepal that made carbon payments to forest user groups, we examine if community forestry institutions can be effective, efficient, and equitable in implementing Reducing Emissions from Deforestation and Forest Degradation (REDD)+. Our evaluation relies on focus group discussions, meetings, and community and program documents of forestry user groups that participated in the REDD+ pilot and matched groups that did not. Compared to control groups, REDD+ user groups appear to be more effective in carbon sequestration, perhaps because of increased prevention of forest fires and grazing, nursery establishment, and other forest management. REDD+ user groups report a larger number of forest conservation, forest utilization, and community development activities relative to control groups. Participating communities bear transaction costs of US $\$ 4.5 /$ hectare and implementation costs of US\$2.5/hectare on average (or NPR 50,000 (US\$600) per year). The mean REDD+ rent per ton of additional carbon sequestered was US\$1.3. Targeting of benefits improves partly because some marginalized groups, particularly women, participate more in the planning and management. In terms of equity, microcredit and capacity development activities were skewed to the poorest households, whereas alternate fuel and carbon monitoring were more advantageous to middle or high income households. Overall, our analyses suggest that REDD+ activities can be successfully executed, if communities receive technical and capacity building support for institutional strengthening, in addition to carbon payments.
\end{abstract}

Key Words: cobenefit; effectiveness; efficiency; equity; REDD+

\section{INTRODUCTION}

The Conference of Parties to the United Nations Convention on Climate Change endorsed the role of forests in climate mitigation in Paris in 2015. "Reducing Emissions from Deforestation and Degradation (REDD)" and "REDD+," which includes forest carbon enhancement through sustainable forest management and conservation, is a critical mechanism in implementing the "global deal" negotiated at the 21 st Conference of Parties (UNFCCC 2015). REDD+ seeks to incentivize climate change mitigation by creating markets to sequester and store carbon in forests (Balooni and Lund 2014). If successful, REDD+ has the potential to reduce around 12 to $20 \%$ of global greenhouse gas emissions by allowing high carbon emitting countries to pay forest conserving developing countries (FAO/UNDP/UNEP 2008, World Bank 2009, Springate-Baginski and Wollenberg 2010, Corbera and Schroeder 2011, Visseren-Hamakers et al. 2012).

Interest in REDD+ has spawned several experimental projects to assess policy processes that can contribute to implementation and potential social and environmental implications (Angelsen et al. 2012, Brockhaus et al. 2014a, Sills et al. 2017). Whether REDD+ projects are successful will likely depend on how effective they are in sequestering carbon and whether this is done in an efficient and equitable manner (Angelsen et al. 2009). Effectiveness requires that net carbon emission reductions from REDD+ implementation are positive and stored carbon is "additional" to any mitigation that may occur in a business-as-usual scenario. Also, REDD+ would need to be less costly than any alternate mechanisms (Angelsen 2008, Angelsen et al. 2009). Further,
REDD+ would need to be incentive-compatible, i.e., benefits would need to be greater than any costs borne by local stakeholders (Luttrell et al. 2013). In addition to meeting these " $3 \mathrm{E}$ " criteria, there are many implementation challenges related to monitoring, reporting, and verification (MRV), safeguards and interagency coordination (Angelsen 2008, Visseren-Hamakers et al. 2012).

Large numbers of people around the world are dependent on forests for their livelihood needs (FAO 2014, World Bank 2016). Forests are a source of subsistence goods, wage income, insurance, wealth, and multiple ecosystem services (Pattanayak and Sills 2001, MEA 2005, Ferraro et al. 2012, Angelsen et al. 2014). The expectation is that REDD+ can add to the welfare of forestdependent communities and produce cobenefits by conserving biodiversity and ecosystem services through better forest governance (Sunderlin et al. 2010, den Besten et al. 2014). However, implementation of carbon trade will require a range of actors, organizations, and institutions to join hands (Brockhaus et al. 2014a,b). Although global carbon markets promise additional revenues to local communities, they also pose some risks because revenues are uncertain and communities have heterogeneous preferences over different forest products and services (Schroeder and McDermott 2014). Thus, even as global agreements push the "forests for carbon" agenda, it is vital to identify the trade-offs between carbon sequestration, other forest land uses, and poverty reduction for forest-dependent households (Chhatre and Agrawal 2009, Pokorny et al. 2013, Schroeder and McDermott 2014).

\footnotetext{
${ }^{1}$ Tribhuvan University, ${ }^{2}$ South Asian Network for Development and Environmental Economics (SANDEE), ${ }^{3}$ The Nature Conservancy, ${ }^{4}$ Duke University, ${ }^{5}$ International Centre for Integrated Mountain Development
} 
Fundamental to REDD+'s success is the nature of the institutions that facilitate the trade between sellers and buyers of forest carbon (Bushley and Khatri 2011, Corbera and Schroeder 2011, Lederer 2012). Trade-offs and synergies between current forest uses and its usage for carbon sequestration will depend on how existing policies and institutions adjust to accommodate carbon markets (Smith and Scherr 2003). Although an international architecture is slowly emerging for forest carbon trade, of equal importance are the national and local forest management institutions (Chhatre and Agrawal 2009, Collen et al. 2016). Many questions remain about how well these nested institutions can facilitate transactions in carbon, a relatively new marketable attribute of forests, and how they may need to be modified to deliver this service (Hayes and Persha 2010, Balooni and Lund 2014). In this paper, we add to this emerging literature by examining the role of local community institutions in REDD+ implementation.

Community-based forest management is a form of decentralized management that seeks to improve the quality and stock of forests by strengthening user rights and allowing users to collectively manage local forests (Shyamsundar and Ghate 2014). Globally, community control over forests increased from some $21 \%$ of forests lands in 2002 to $30 \%$ in 2013, even though this positive trend is largely restricted to Latin America and China (Rights and Resources Initiative 2014). There is also evidence that points to the effectiveness of communities in managing forests (Agrawal and Angelsen 2009, Somanathan et al. 2009, Seymour et al. 2014, Newton et al. 2015). Given the concurrence between community forestry and REDD+ goals, it is useful to ask whether and how REDD + can be implemented in community-managed forests (Balooni and Lund 2014, Newton et al. 2015).

Our research examines the role of local institutions in carbon trade by focusing on community-managed forests in Nepal. Nepal is a diverse country with ecosystems that range from high mountains to flat lands and a population that includes some 125 different ethnic groups (CBS 2012). In this relatively small country, about $45 \%$ of land is classified as forests (MOF/GON 2016). Although Nepal emits only 0.1 metric tons of $\mathrm{CO}_{2}$ per capita relative to a global average of 4.7 (World Bank 2013), its forest carbon density is comparable to large carbon rich countries such as Indonesia and Brazil (FAO 2011). Nepal is preparing itself for carbon trade by reorganizing government agencies, obtaining financial support from international organizations, and undertaking various projects to test different options for sequestering carbon (RFCCC/MFSC 2013, RIC/MSFC 2015).

In this paper, we examine local responses to carbon payments by studying a community forest-based REDD+ pilot program in Nepal. We ask if community institutions can reorganize to deliver carbon sequestration services in addition to livelihood benefits. How costly is this reorganization? Can payments be distributed in an equitable manner to elicit broad support for REDD+? Our analysis allows us to draw lessons for community forestry-based REDD+ in Nepal and the rest of the world.

\section{REDD+ READINESS IN NEPAL}

There is currently much interest and planning in Nepal to sequester forest carbon through REDD+ (Paudel et al. 2013). In 2011, Nepal was one of the first countries to receive international financial support for REDD+ preparedness from the Forest Carbon Partnership Facility (FCPF) of the World Bank. It has also received support from UN-REDD to undertake different
REDD+ related activities (RFCCC/MFSC 2013). Most recently, the government was promised a US\$24 million grant plus loan to improve forest management and ready itself for REDD+ markets (REDD+ Implementation Centre, Government of Nepal, personal communication).

The Government of Nepal has developed a three-tiered structure to get ready for carbon markets. It has created an "Apex" interministerial body for multisectoral coordination, a REDD Working Group for technical support and strategy, and a REDD Implementation Centre that is responsible for executing REDD+ programs. In addition, many civil society institutions are trying to ensure that REDD+ implementation follows an inclusive process (Shrestha et al. 2014, RIC/MFSC 2015).

Updated official statistics state that forests cover about $45 \%$ of Nepal (MOF/GON 2016). Nepal has also assigned 23\% of its land area as protected areas (MFSC/GON 2014), though not all this land is forested. Of the total designated forest area, community forests cover around $27 \%$, followed by leasehold and partnership forests, which cover another $2 \%$ of forest land (MOF/ GON 2016). In addition to community forests and protected areas, the Government of Nepal directly manages forests through district, sectors, and area (Ilaka) forest offices. There is significant uncertainty over the state of the forest area that is government managed. These forests, which cover some of the most valuable and carbon rich forests in the Southern Terai and the Siwalik hills of Nepal, have seen an annual estimated $0.4 \%$ loss in forest cover during 1991-2010 (FRA/DFRS 2014). Limited institutional capacity to monitor infractions and high demand for timber have contributed to degradation and deforestation (MFSC/HMGN 2000). REDD+ implementation in Nepal is expected to focus on community managed forests, in addition to government managed forests (MFSC/GON 2013).

The opportunity to participate in new markets for forest carbon raises many policy uncertainties in Nepal (Paudel et al. 2013, Newton et al. 2015). One concern is whether carbon management would require large-scale forest management with a leading role for the government in carbon measurement, reporting, and verification (MRV) and international negotiations. Could this lead to a reversal in Nepal's policy of decentralized forest management achieved through decades of effort and legislation (Phelps et al. 2010, Bushley and Khatri 2011)? Second, there is anxiety about carbon services dominating livelihood and biodiversity services and potential restrictions on forest resource use (Adhikari 2009). This raises questions about whether REDD+ payments will change ongoing community activities. Third, there is debate over criteria for distributing REDD+ payments (DANAR-Nepal 2012). There are also uncertainties about the types of forests and management regimes that may be amenable to carbon sequestration (Dhital 2009, Bastakoti and Davidsen 2014). These concerns have begun to heighten social and political tensions, making it essential to follow an incremental learning-by-doing approach. Similar pressures simmer in other parts of the world where REDD+ is being implemented (Pokorny et al. 2013, Schroeder and McDermott 2014).

\section{CONSERVING CARBON THROUGH COMMUNITY FORESTS}

In forestry circles, Nepal is well known for its community forestry program in the middle-hill areas (Dev et al. 2003, Bushley and Khatri 2011). These forests are governed by approximately 18,960 
community forestry user groups (henceforth, user groups) that involve approximately $40 \%$ of the households in the country (CBS 2011, MOF/GON 2016). Although the state owns the forests, communities, in collaboration with the Forest Department, decide how best to conserve and use these forests, particularly to meet subsistence needs. Thus, elected local committees make decisions regarding forest access and use, penalties related to rule violation, and disbursement of fines and funds.

Although there is no large-scale evidence to suggest that any one type of forest management is better at enhancing carbon stocks, numerous studies identify community forestry as an effective, even superior, forest management strategy relative to state forestry in the Himalayan region of Nepal and India (Nagendra et al. 2005, Nagendra 2007, Kanel 2008, Somanathan et al. 2009, Baland et al. 2010, Miteva et al. 2012). Empirical research suggests that extraction of forest goods such as fuel wood is lower in community forests relative to state managed forests in Nepal (Edmonds 2002, Tachibana and Adhikari 2009). Thus, strengthened management rules and tenure seem to help reduce grazing and forest product collection (Nagendra 2007, Tachibana and Adhikari 2009). Community groups are also able to respond to signals of forest change more rapidly and introduce conservation practices such as stall feeding of cattle, forest fire prevention, encouraging tree plantation in private land to meet daily needs, and guarding against illegal felling (Nagendra 2007, Nepal et al. 2007, Kanel 2008, Pokharel 2012). Evidence also points to community forestry being a relatively less expensive strategy to conserve forests in the Indian Himalayas (Somanathan et al. 2009).

\section{Experimental carbon payments}

To better understand how REDD+ may work in Nepal, several organizations joined hands in 2009 to execute a pilot carbon payments program in community forests. ${ }^{[1]}$ With support from the Norwegian Agency for Development Cooperation's Climate and Forest Initiative, they created the Forest Carbon Trust Fund as a mechanism to make payments to user groups for conserving carbon. The fund operated in three distinct ecosystems: the Charnawati watershed in Dolkha district (mountains), Ludikhola watershed in Gorkha district (hills), and in Kayarkhola watershed in Chitwan district (plains; see Fig. 1). These watersheds cover some 10,000 hectares of community-managed forests, involving more than 18,000 households. All 105 user groups in the watersheds participated in the program from 2011 to 2013 (Shrestha et al. 2014).

Fig. 1. Map of study districts.

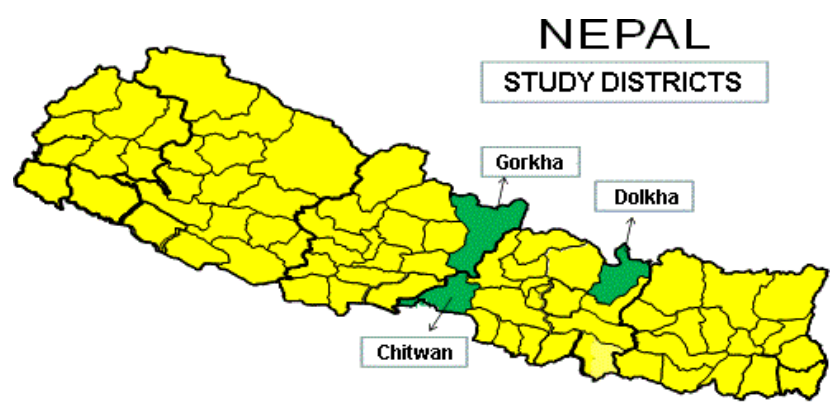

To create an incentive system for carbon sequestration, the Fund distributed a total sum of US\$95,000 each year for three consecutive years (2011-2013) to participating user groups. Payments were provided to management committees along with guidelines for fund allocation. Further, instead of a pure market type transaction, the carbon payment was designed to be a function of carbon and social safeguard indicators with differing weights: (i) carbon stock in the base year $(24 \%)$, (ii) carbon increment each year (16\%), (iii) indigenous group household (10\%), (iv) Dalit household (15\%), (v) poor households $(20 \%)$, and (vi) gender ratio (15\%; Shrestha et al. 2014).

The user groups disbursed the carbon funds to their members for a variety of preidentified activities that reduced deforestation, conserved and enhanced forest carbon, and reduced poverty and improved livelihoods. Funds were disbursed for activities related to reducing deforestation, alternative energy promotion, biodiversity conservation, forest carbon stock enhancement, livelihood improvements, and auditing and data verification (CFRPN 2011). Funds were also used to raise awareness on REDD+, support accounting and banking practices within the groups, identify ways to be more inclusive in community activities, and build community capacity in carbon monitoring (Shrestha et al. 2014). Households did not generally receive any REDD+ cash payments directly. However, microcredit was offered through the user groups for undertakings related to retail shops, vegetable farming, and livestock purchases.

This program was implemented with close coordination between district forest officials and local communities in accordance with the operational guidelines of the Forest Carbon Trust Fund. At the district-level, activities were supervised by an advisory committee made up of Federation of Community Forest Users, District Forest Officials, REDD+ network of user groups, and a REDD+ Monitoring Committee, which sought to ensure that claims received, payments made, and carbon databases were accurate. The REDD+ Network, informed by the District Advisory Committee, instructed user groups on how to implement different activities (CFRPN 2011). Subsequently, user groups conducted workshops and awareness campaigns related to capacity building, livelihood improvements, forest carbon monitoring, alternative energy use, etc. and distributed funds. The three-year program was closed in 2013 upon successful completion. We examined this pilot program to assess how effective, efficient, and equitable community forestry institutions can be in implementing REDD+. Community forestry operates through local organizations, has legal and practical ties to the forest department, and includes rules and norms regarding forest use. Thus, it is a tested forest management system that can potentially be used as a building block for REDD+ (Chhatre and Agrawal 2009, Newton et al. 2015). For REDD+ to be successful, the literature points to three important management criteria: carbon effectiveness, cost efficiency, and equitable distribution of benefits, including cobenefits (Angelsen 2008, Sunderlin et al. 2010, Corbera and Schroeder 2011, Costenbader 2011, Murdiyarso et al. 2012). Thus, for community-based forest management to be a useful vehicle for REDD+ implementation, it must effectively and efficiently contribute to carbon sequestration and enable equitable distribution of resulting benefits. 
Table 1. Indicators of effectiveness, efficiency, equity, and cobenefits.

\begin{tabular}{ll}
\hline \hline Criteria for meeting REDD+ goals & Indicators \\
\hline Management Effectiveness & General body meeting held this year (Yes/No) \\
& Number of executive committee meetings this year \\
& Ethnicity and wealth profiles updated this year (Yes/No) \\
& Was forest fire in community forest prevented this year (Yes/No) \\
& Were any major border conflicts resolved (Yes/No) \\
& Percentage of prescribed forest management activities undertaken this year \\
& Transaction costs from REDD+ related meetings, awareness campaigns, delegations to the Forest Office, \\
& etc. \\
Cost Efficiency & Implementation costs of REDD+ activities related to construction of forest fire protection trenches and \\
& any equipment and food purchased for meetings and forest management. \\
& REDD+ Payments received \\
& Percentage of women in executive committees \\
Equity Indicators & Percentage of Dalit and indigenous groups in executive committees \\
& Percentage of community forest user groups that conducted Tole (subhamlet)-level meetings \\
Cobenefits (perceptions measured on a & Forest quality improvement \\
Likert scales with lowest $=1$ and highest $=$ & Livelihood improvements of poor and marginal households \\
$5)$ & General livelihood improvements \\
& Institutional development \\
& Community development activities \\
\hline
\end{tabular}

\section{METHODS AND DATA}

We examined a set of indicators related to effectiveness, efficiency, and equity (Table 1) based on the REDD+ pilot program that ran from 2011 to 2013 . $^{[2]}$ We examined carbon data as well as institutional actions undertaken by user groups that received REDD+ seed grants. Where possible, we compared indicators with information from other similar non-REDD user groups (Pattanayak 2009). To assess whether user groups are effective institutions, we first examined community forest data on carbon sequestration to gauge whether community-managed forests can contribute to carbon growth. Subsequently, we used six indicators of management effectiveness (Springate-Baginski et al. 2003, Wertz-Kanounnikoff and McNeill 2012, Maraseni et al. 2014) to compare communities that received REDD+ financing with control user groups that did not receive any such funding. Our indicators of "functional" effectiveness included frequency of general body and executive meetings of community forest user groups and membership record. Forest fire prevention, major conflict resolution, and an increase in forest management are additional indicators of "active" governance (MFSC/GON 2009, Acharya et al. 2011, MFSC/UN-REDD/Forest Action 2014). ${ }^{[3]}$ Positive differences in these indicators would suggest that an infusion of REDD+ resources is compatible with strengthened forest governance.

Any new forest management activities come with certain costs. We assessed cost effectiveness by estimating REDD+ rents to communities, i.e., deducting costs from payments received per unit of carbon sequestered. Costs of sequestering forest carbon through REDD+ are often categorized into implementation, transactions, and opportunity costs (Lutrell et al. 2013). Implementation costs are generally incurred during measurement, monitoring, verification, reporting, and organization of carbon payments. Transaction costs emerge from establishing and maintaining property rights over forests and carbon. The opportunity cost is the benefit from the next best profitable alternative use of forests and forested land other than carbon sequestration. In our analyses, we focused on transaction and implementation costs incurred by community forestry user groups involved in the REDD+ pilot. ${ }^{[4]}$ Implementation costs to user groups resulted from labor used in construction of fire lines and protection trenches and any equipment and food purchased for meetings and forestry activities. ${ }^{[5]}$ Transaction costs included costs associated with time spent on REDD+ related management committee meetings, village-level meetings, delegations to district forest office, and awareness campaigns.

An important consideration is whether REDD+ benefits can be equitably distributed and what some of the cobenefits may be. REDD+ promises to infuse local communities with new resources. Fair distribution of these resources could help support the government of Nepal's poverty reduction goals, meet community forestry's gender and ethnic equity guidelines and ensure broad-based support for forest protection (Poudel et al. 2014). Both procedural and distributive equity may be required if institutional frameworks are to be supportive of REDD+ environmental goals (McDermott and Ituarte-Lima 2016). In our analyses, we first examined indicators of procedural equity such as participation in decision making. These indicators identified the presence of women and low caste communities in forest management committees and Tole- or subhamlet-level participation in community forestry activities. Subhamlet-level meetings ensure that the interests of marginalized and distantly located groups are considered. We also assessed how the benefits from REDD+ related community energy, microcredit, and skill development programs are distributed among various stakeholders.

Institutional development, forest quality and biodiversity, poverty reduction, and local livelihood and community development are desired cobenefits associated with REDD+ (Brown et al. 2008, Wertz-Kanounnikoff and McNeill 2012). To identify cobenefits in Nepal, we gathered perception data through focus group discussions in REDD+ user groups. We use a Likert scale to evaluate whether carbon financing can contribute to cobenefits. 
Table 2. Community and household characteristics of sampled REDD+ and non-REDD+ communities (2011).

\begin{tabular}{|c|c|c|}
\hline Characteristics & $\begin{array}{l}\text { REDD (Treatment) } \\
\text { Mean }(\mathrm{n}=135)\end{array}$ & $\begin{array}{c}\text { Non-REDD (Control) } \\
\text { Mean }(\mathrm{n}=135)\end{array}$ \\
\hline \multicolumn{3}{|l|}{ Community Characteristics } \\
\hline Years of CF operation & $11.11(2.03)$ & $8.22(1.69)$ \\
\hline Households per hectare of $\mathrm{CF}$ & $1.95(0.41)$ & $2.26(0.48)$ \\
\hline Number of local organizations & $4.22(0.55)$ & $4.22(0.60)$ \\
\hline Distance to public institutions (minutes) & $98.33(17.39)$ & $97.92(17.33)$ \\
\hline Indigenous and Dalit HHs (percent) & $82.33(3.50)$ & $63.67(11.90)$ \\
\hline \multicolumn{3}{|l|}{ Household Characteristics } \\
\hline Household size & $5.09(0.17)$ & $5.35(0.19)$ \\
\hline Literate household head (percent) & 71.85 ( 3.89$)$ & $73.33(3.82)$ \\
\hline Agriculture landholding (hectares) & $0.52(0.04)$ & $0.56(0.05)$ \\
\hline Firewood from CF(loads) & $22.66(1.74)$ & $22.99(2.12)$ \\
\hline Annual forest income (thousand Rs.) & $52.32(2.30) * * *$ & $61.21(2.63)$ \\
\hline
\end{tabular}

To understand how effective the user groups were in organizing themselves for REDD+, we collected data from a sample of nine REDD+ user groups in three watersheds covered by the REDD+ pilot program and nine control groups in nearby areas. These 18 user groups were drawn from a larger data set of matched nonREDD and REDD+ user groups (for details see Sharma et al. $2015 b$ ). Our subsample of 18 user groups match on various forest management indicators, which were identified through discussions with district executive committee members of the Federation of Community Forest Users in Nepal.

Thus, we collected institutional data from 18 user groups over a two-year period, 2011 when the REDD+ incentive payment was introduced and 2012 when the program had been in place for one year. Data were collected through focus group discussions. Each focus group discussion included executive committee members, regular members, and local key informants such as social workers and teachers. We obtained information on the number of activities undertaken, who participated in REDD+ activities, and processes followed for different activities. Structured and semistructured questions were used to obtain indepth and perception-related information.

We also obtained secondary data from community records such as committee meeting minutes and related documents from 2010/2011 and 2011/2012. Additional information such as amount of carbon payments and changes in carbon stock was collected from the central project office. Household data collected from a larger group of REDD+ and non-REDD+ groups, as discussed in Sharma et al. $(2015 b)$, were also used to triangulate evidence.

\section{RESULTS}

Efficiency, effectiveness, and equity

Prior to the REDD+ pilot, the REDD+ and non-REDD+ forest user groups analyzed in this paper were similar. Table 2 shows that on average, communities had been managing their forests for 8 to 11 years and the density of population to community forests was 2 households per hectare. Both groups had equal access to local and external organizations and to public facilities such as high school, health post, police station, and banks. The REDD+ groups appear to have a higher percentage of indigenous and Dalit ${ }^{[6]}$ household users, but these differences were statistically insignificant. The average household size is about 5 members in the sample and about $72 \%$ of heads of household were literate. Agricultural land holding is some 0.5 hectares. Community forests per household were on average 0.65 hectares and 0.72 hectares in the REDD+ and control strata.

\section{Management effectiveness}

An examination of carbon in the REDD+ forest user groups over a one-year period suggests that carbon stock increased by approximately three tons per hectare in the nine REDD+ communities during 2010-2011 (ICIMOD/ANSAB/FECOFUN 2012). This is equivalent of around 11 metric tons of $\mathrm{CO}_{2} \cdot{ }^{[7]}$ Thus, local institutions can ensure that carbon is sequestered in community forests (see Fig. 2). Although these results are not attributable to REDD+ payments, they reflect the compatibility between REDD+ and community-based Forest Management.

Fig. 2. Carbon increment, REDD+ revenue, costs, and rent. Revenue and cost calculated on the basis of payments received, and transaction and implementation cost incurred at the community level by the sample community forest user groups divided by the increment in carbon in the associated community forests, 2010-2011. Rent is the difference between revenue and costs. Source: ICIMOD/ANSAB/FECOFUN (2012) and Data from Focus Group Discussions (2012).

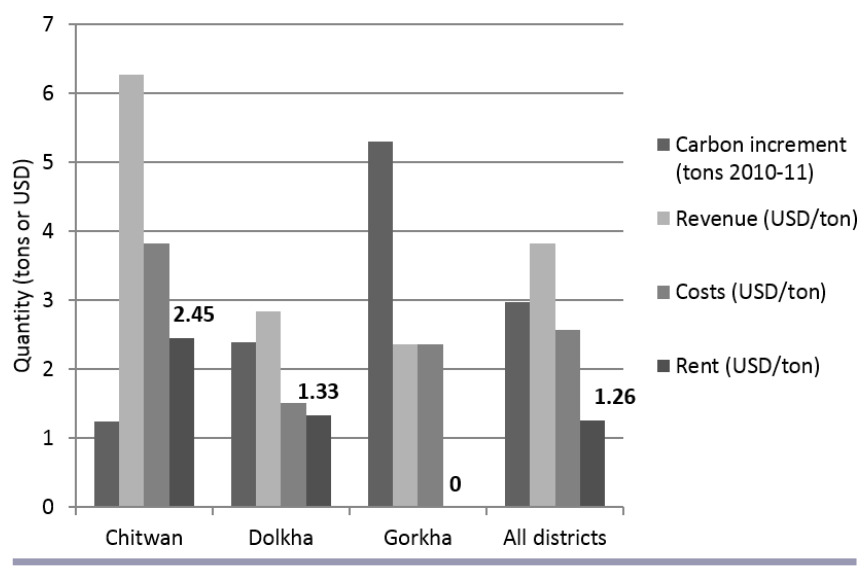


Table 3. Indicators of management effectiveness.

\begin{tabular}{|c|c|c|c|c|}
\hline Indicators & REDD+ CFUGs & Non-REDD+ CFUGs & $\begin{array}{l}\text { Difference } \\
\text { t-statistics }\end{array}$ & Inference $^{\dagger}$ \\
\hline EC meetings per year (mean) & 15.0 & 9.0 & $2.59 * *$ & Better \\
\hline $\begin{array}{l}\text { General assembly meetings } \\
\text { (percent) }\end{array}$ & 100.0 & 77.8 & 1.51 & No difference \\
\hline Updated ethnicity and wealth profiles (percent) & 100.0 & 33.3 & $4.00 * * *$ & Better \\
\hline $\begin{array}{l}\text { Forest fire surveillance system during risk months } \\
\text { (percent) }\end{array}$ & 100.0 & 55.6 & $2.52 * *$ & Better \\
\hline CFUG border conflicts resolved (percent) & 22.2 & 0.0 & 1.51 & No difference \\
\hline Guideline activity category undertaken (percent) & 62.2 & 51.1 & 10 & No difference \\
\hline
\end{tabular}

To understand if the REDD+ financing contributed to better forest management, we examined six indicators of institutional effectiveness. Table 3 shows that REDD+ user groups did significantly better than non-REDD+ groups in terms of the number of executive committee meetings per year. There is, however, no clear difference in terms of the number of general assemblies held. User groups are required to hold a general assembly at least once a year in which the executive communities are democratically elected, annual revenue and expenditure publicly audited, and programs and policies are approved. REDD+ groups systematically updated their records, particularly on the ethnicity profile of their membership. Maintaining records of members and their participation is important because this ensures that funds are systematically allocated. Most nonREDD+ groups did not maintain good records. These findings, which suggest that REDD+ user groups were more actively engaged in making forest management decisions, confirm the findings in Poudel et al. (2014).

The REDD+ seed grant was a strong motivation for forest fire surveillance. One REDD+ user group committee member in Shikhar, Gorkha noted the following:

A single forest fire can destroy forest protected through
years of efforts. After REDD+ was introduced, we are
very concerned about the value of protecting the trees
and have made effective provision of surveillance
employing user group members during the four risky
months. The carbon payment offset this surveillance cost.

Some non-REDD+ user groups also had such a system in place during forest fire prone months. However, all the REDD+ user groups made sure that small groups of community members were given the responsibility of addressing forest fires or paid to keep vigil during the dry season.

Conflicts over community forests occur because of border encroachments. In a few user groups these were resolved through the active involvement of the project-created REDD networks because they could get the attention of the District Forest Office. However, such conflicts were limited and there are few differences in penalties imposed between REDD+ and non-REDD+ user groups. Minor cases of animal grazing received verbal reprimands.

We also analyzed whether community institutions undertook the forest conservation and development identified in the community forestry guidelines of the Department of Forests. The guidelines categorized activities into nine major activities. Figure 3 shows that REDD+ user groups did better than non-REDD+ groups in terms of forest conservation, forest utilization, and community development. REDD+ communities, on average, undertook $62 \%$ of the activities listed in the guidelines. These included tasks such as prevention of fires, controlling open grazing and encroachment, nursery establishment and afforestation, removing deadwood and leaves, nontimber plantations, soil erosion control, institutional development training workshops, and local livelihood improvement programs. On the other hand, the non-REDD+ user groups undertook only $51 \%$ of such activities.

Fig. 3. Mean values of different activities undertaken by REDD+ and non-REDD community forest user groups. Source: Data from Focus Group Discussions (2012).

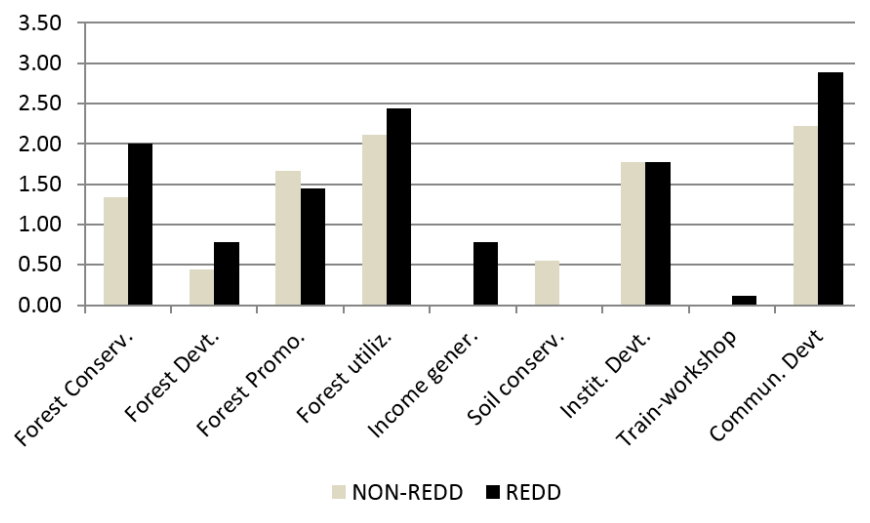

\section{Cost efficiency}

To assess cost efficiency, we examined implementation and transaction costs incurred by the REDD+ user groups. Transaction costs were limited to community costs and did not include the costs incurred in implementing REDD+ nationally. REDD+ rent refers to payments received over and above costs.

Transaction costs reflected the time community members spent in REDD+ related meetings, training, and delegations to district offices. The mean REDD+ transaction costs in an average user group was US\$4.5 per hectare of community forests (see Fig. 2). 
Table 4. Impact of REDD+ on participation in decision making (2012).

\begin{tabular}{llccc}
\hline \hline Criteria & Indicators & \multicolumn{2}{c}{ Change percent } & Inference \\
\cline { 3 - 4 } & & REDD+CF & Non-REDD+CF \\
\hline Equity & Female members in EC (2011-2012) & +7 & -4 & Better \\
& Indigenous members in EC (2011-2012) & -2 & -6 & Relatively better \\
& Dalits in EC (2011-2012) & 0 & -1 & Relatively better \\
& Tole-level interactions on CF benefit sharing & +33 & Better \\
\hline Inference based on changes in arithmetic mean figures; & & +0 \\
EC indicates executive committee; Tole is subhamlet; CF indicates community forest; \\
Source: Field observations and Data from Focus Group Discussions (2012).
\end{tabular}

The implementation costs were the cost of constructing forest fire protection trenches and equipment and costs related to forest management activities specifically related to REDD + . The mean implementation cost per user group was around US\$2.5 per hectare. Thus, transaction costs were almost twice the implementation costs. Transaction costs were expected to be high during the initial years and are likely to fall overtime. As Figure 2 shows, the average user group received US\$8.9 per hectare in REDD+ receipts. Thus, REDD+ rent was around USD 2 per hectare.

At the community user group level, the combined transaction and implementation costs in the first year of the REDD+ project was approximately US\$725 per user group. The average REDD+ payment received was around US $\$ 1000$ per user group. Thus, REDD+ rent was around US\$275 per user group in the initial year.

As mentioned above, Figure 2 shows the carbon sequestered during the first year of the program. For this carbon, communities, on average, received a carbon payment of US\$3.8 per ton of carbon. The mean combined transaction and implementation costs to the communities were US\$2.6 per ton. Thus, the mean REDD+ rent per ton of additional carbon sequestered were around US\$1.3. Transaction and implementation costs per ton were about two-thirds of the REDD+ payment.

As evident in Figure 2, there was considerable variation in the carbon payment receipt, costs, and rents per ton of carbon stored. Chitwan had the lowest carbon increment, yet highest receipt per ton of carbon. On the other hand, Gorkha, with the highest carbon increment per hectare, earned zero rent. ${ }^{[8]}$ This is because of the high costs that the Gorkha user group incurred for forest fire surveillance based on their historical experience of forest fires. Households undertook this responsibility in a rotational manner and earned income for fire surveillance.

\section{Equity and cobenefits}

We assessed equity and cobenefits emerging from the REDD+ efforts by first comparing gender and ethnic group representation in executive committees of user groups that received funds with those that did not. This is important because participation of marginalized groups such as the women, indigenous people and the Dalits in decision making is limited in Nepal, even though inclusiveness is mandatory in public and community institutions. Furthermore, because of highly scattered settlements with marginal groups often living in the peripheries, effective participation in community forestry requires interactions at the hamlet and subsettlement (Tole) level. Thus, we also examined the extent to which Tole-level participation changed when REDD+ payments were made (see Table 4). Third, we scrutinized the distribution of REDD+ funds among different income, caste, and gender beneficiaries.

Our findings from comparing data from REDD+ and nonREDD+ user groups suggest that women's participation in decision making improved in the REDD+ communities. As Table 4 shows women's participation in executive committees increased by $7 \%$ in REDD+ user groups, while there was a $4 \%$ decrease in the non-REDD+ user groups. In some progressive communities, REDD+ pilot activities clearly strengthened the role of women. One Devidhunga community member noted the following:

It is mostly women who participate in the REDD+ meetings now a days. They are concerned ...that extraction is not restricted but forest degrading practices such as open grazing and cutting green stems are discouraged.... Now we have planted plants that provide fodder to our livestock and twigs that can be a substitute for firewood.

Interestingly, Poudel et al. (2014), who examine three user groups in the region, are more skeptical about improvements in the role of women in decision making. Although the REDD+ program seems to have increased support for women in forestry, social change in terms of true participation is likely to be uneven and slow.

Table 4 suggests that REDD+ activities may not have contributed to significant changes in caste and group related participation in decision making. In both REDD+ and non-REDD+ user groups, indigenous members in executive committees declined slightly but there was smaller decrease in REDD + groups. Dalit representation remained stable in REDD+ groups, but declined in non-REDD areas. However, this decline was toward normalization because they were previously slightly overrepresented. ${ }^{[9]}$ The improved participation of marginalized groups in REDD+ communities is consistent with Maraseni et al. (2014). Our perception is that these small changes reflect ongoing social and political dynamics rather than being related to REDD+ payments. Tole-level meetings, which were used to consult poor and marginalized households in distant hamlets, took place only in the REDD+ groups.

Figures 4, 5, and 6 show how REDD+ funds were distributed to different beneficiaries within the user groups that participated in the REDD+ pilot. Poverty and the livelihood improvement funds, 
including provision of microcredit, were meant for low and middle income households. Figure 4 shows that between 70 to $80 \%$ of the beneficiaries of these programs were indeed households that belonged to these income groups. Discussions with community members suggest that the REDD+ program helped in changing perceptions regarding microcredit to the poor and their ability to repay loans. However, carbon monitoring, which requires some literacy, was less beneficial to lower income households. The alternative fuel program was also more skewed toward the middleincome group because it needed assets such as cattle and permanent toilets. Overall, there is a sense that REDD+ pilot programs focused on the poor within their communities and this is validated by some other studies such as Poudel et al. (2014).

Fig. 4. Beneficiaries of REDD+ activities by income groups. Source: Data from Focus Group Discussions (2012).

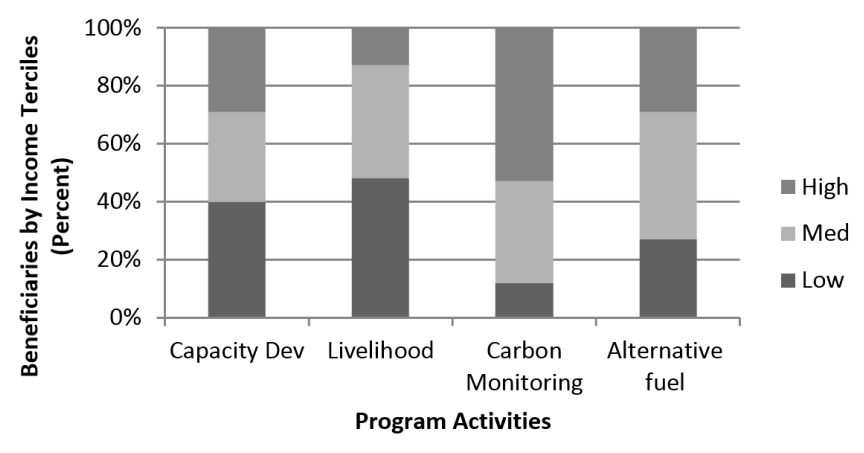

Fig. 5. Beneficiaries of REDD+ activities by ethnic groups. Source: Data from Focus Group Discussions (2012).

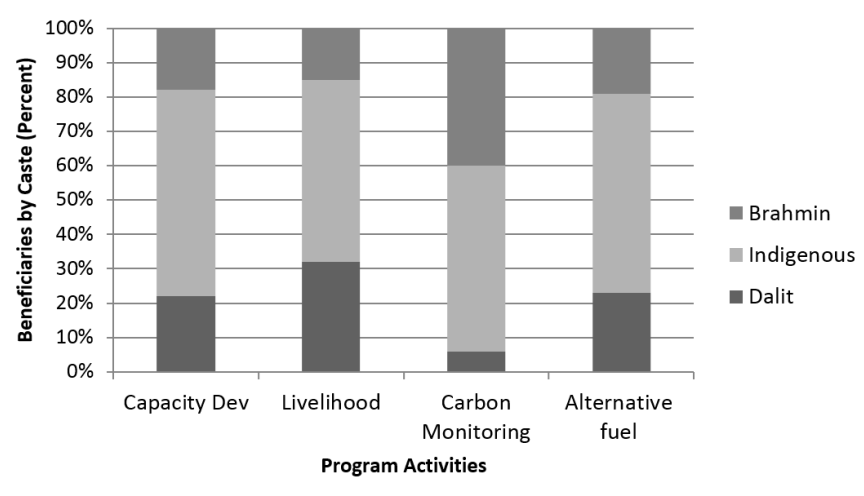

Figure 5 shows that REDD+ capacity development programs' benefits were weighted more heavily toward underserved groups, i.e., the Dalits and indigenous groups. Twenty to thirty percent of the beneficiaries from livelihood, capacity building, and alternate fuels programs were Dalits, considered the most deprived community in Nepal. However, they were the smallest group benefitting from carbon monitoring, which was skewed toward the upper caste. This possibly reflects that fact that most Dalit are illiterate.
Fig. 6. Gender distribution of REDD+ activity beneficiaries. Source: Data from Focus Group Discussions (2012).

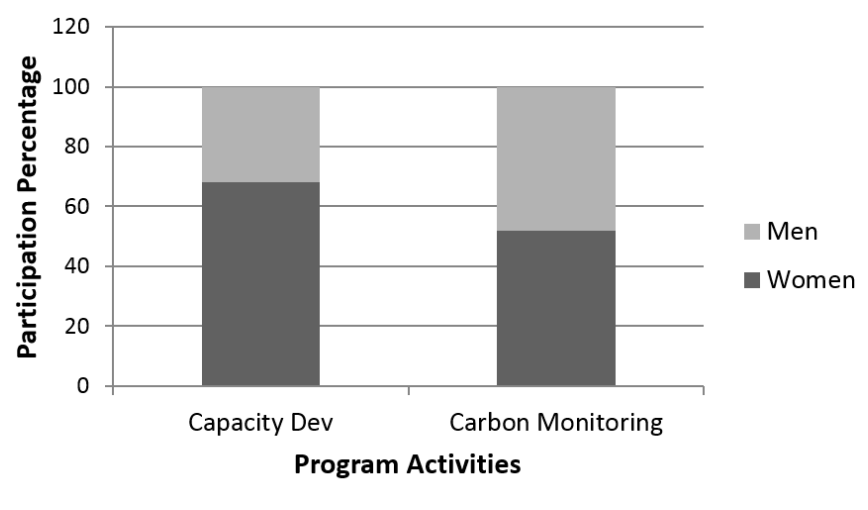

In terms of female beneficiaries, livelihood improvement and alternative fuel benefits were gender neutral because they were utilized at the household level. However, women benefitted from REDD+ capacity developing training. At least $50 \%$ of the employment in carbon monitoring went to women (see Fig. 6).

Our final set of indicators focuses on cobenefits. Figure 7 shows community perceptions on five indicators of cobenefits recorded on a Likert scale ranging from 1 to 5 (very low to very high). As perceived by community members, institutional development was the strongest cobenefit from the REDD+ pilot. The villagers saw improvements in forest quality as the next best cobenefit from the program.

Fig. 7. Perceived impacts of REDD+ pilot programs on cobenefits. Source: Data from Focus Group Discussions (2012).

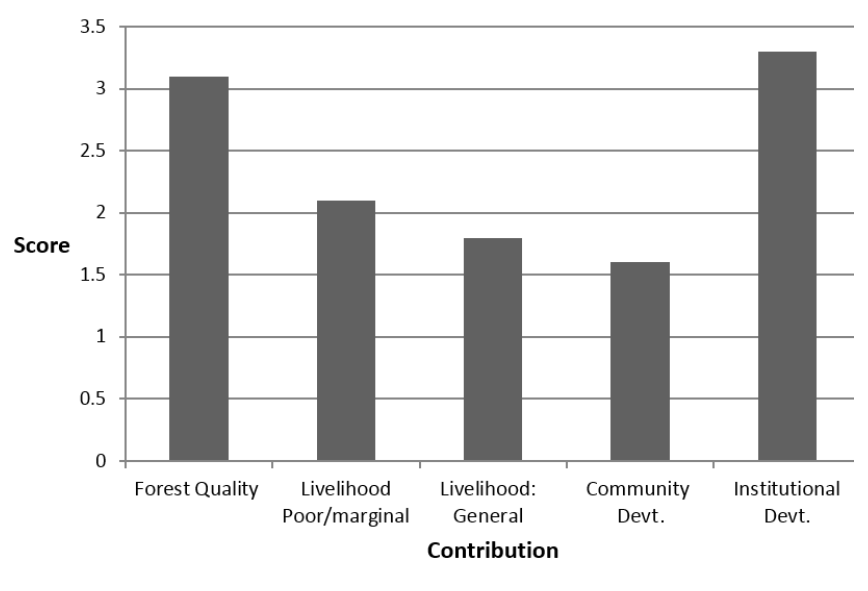

\section{DISCUSSION}

In the nine communities that we studied, forest user groups received an average payment of NPR 81,000 (US\$1000) to undertake activities that would directly and indirectly contribute to carbon sequestration. The payments and associated support appears to have motivated communities to participate in protecting growing forest stocks, undertaking more intensive 
forest-fire surveillance and better managing rotational grazing or stall feeding (Maraseni et al. 2014, Poudel et al. 2014). One community member from Janapragati, Chitwan said the following:

\begin{abstract}
Community members have initiated by themselves measures to ensure that forest fires do not occur, cattle are not grazed in the community forests, only dead wood is collected and while pruning trees growing stocks are protected so that we can reap greater benefits from carbon enhancement in our forests.
\end{abstract}

An important cobenefit from the REDD+ pilot was revitalized community forestry institutions. Participating communities were enthused, updated their membership records, and met more frequently to make community decisions related to forests and fund distribution. Thus, the average community incurred REDD+ related transaction and implementation costs of NPR 59,000 (US\$725). Summed over 18,000 user groups that currently exist in Nepal, this equals approximately US\$13 million per year. This is evidence of the real costs that communities will bear in Nepal in implementing REDD+. However, these initial costs are likely to decline over time.

One important question is whether REDD+ will simply act as an additional source of income for communities or whether this will be a disruptive change and put communities on a different resource extraction trajectory. If the market for carbon grows significantly and carbon prices increase, then communities may begin to manage forests exclusively for carbon. In this scenario, the changes that may occur will be somewhat like those frequently witnessed when small-holders use forests for rubber or oil palm plantations instead of traditional harvesting of fuel wood and nontimber forest products. This type of disruption may reduce forest biodiversity if communities start specializing in growing certain types of trees (Wilcove and Koh 2010). It may also lead to new players entering the market and contribute to a breakdown in cooperation. For instance, in the Terai-belt of Nepal, which hosts more valuable timber, community forestry has been harder to implement (Iversen et al. 2006, Brampton and Cammaert 2007). However, given slow growth in carbon markets, well-established norms and regulations regarding community forest use in Nepal, and ongoing national discussions with stakeholders, it is possible that community institutions will slowly adapt and add the returns to carbon sequestration to the set of current options that forests offer.

Although an overlay of REDD+ over community forests makes sense when we combine carbon needs with existing governance systems that work well for forests, this does not preclude the possibility of other more "optimal" forest carbon management regimes (Newton et al. 2015). Degraded forests that are managed by governments may offer the possibility of higher carbon sequestration and lower MRV costs (relative to community forests). The area under community managed forestry in Nepal is growing annually at a rate of 5 to $8 \%$ (MOF/GON 2010, 2014). Thus, more government managed forests may come under better community management regimes in the future, increasing the scope for carbon sequestration in Nepal. ${ }^{[10]}$

Production forestry in community forests could also enhance timber and carbon returns. Recently, the Government of Nepal started scientific forest management in "collaboratively managed" forests. Scientific management is expected to cover at least $50 \%$ of the forest area in the southern Terai plains, create employment through logging activities, and result in additional revenues of more than US\$300 million, by enhancing biomass productivity (NFA 2011). Introducing scientific management in matured community forests of Nepal may be another strategy to boost carbon storage. Thus, there is ample scope for improving forest management and carbon sequestration in Nepal; whether this happens will depend on how government bureaucracies and local institutions respond to the emerging carbon market.

\section{CONCLUSIONS}

There is a big debate in Nepal's policy circles about where and how REDD+ can be implemented. Therefore, we undertook a qualitative evaluation of a pilot program in Nepal, which made payments to forest user groups to sequester carbon, to ask how effective, efficient, and equitable community forestry institutions can be in implementing REDD+. By using focus group discussions, meetings with knowledgeable experts, and reviewing community and program documents, we examined whether community forest user groups can allow both (i) existing forest uses and (ii) meet international carbon demand. Our examination of a pilot REDD+ program suggests that REDD+ goals are compatible with community forestry. REDD+ activities can be implemented in community forests if communities receive both rents and technical guidance that contribute to institutional strengthening. By identifying some of the strategies that can enable local institutions to better manage forests for carbon sequestration and for equitable outcomes, our research complements and adds nuance to findings from global quantitative assessments that show that community forestry can contribute to carbon sequestration (Agrawal and Angelsen 2009, Chhatre and Agrawal 2009).

In our study, community level transaction and implementation costs range from approximately NPR 111 (US\$1.4) to NPR 1930 (US\$23.8) per hectare per year, with a mean value of NPR 565 (US\$7) per hectare. ${ }^{[1]}$ The mean estimates fall within the range of REDD+ implementation related costs identified in other studies. For example, they are comparable to transaction costs of US $\$ 4$ to 15 per hectare estimated by Grieg-Gran (2006, as cited in Rendón Thompson et al. 2013) for eight tropical countries but slightly higher than US $\$ 4.5$ estimated by Borner and Wunder (2007, as cited in Rendón Thompson et al. 2013) for REDD+ projects in the Brazilian Amazon. They are much higher than estimates by Rendón Thompson et al. (2013) that comprises set up, monitoring, and implementation costs in six sites in the Peruvian Amazon (US\$0.73 per hectare per year). Some of these differences can be explained by major differences in definitions of costs, making comparisons difficult.

Our sample communities are made up of a large percentage of indigenous communities (73 in REDD+ and 53 in non-REDD+ communities). For effective participation of indigenous communities in REDD+ activities, rules need to be implemented at multiple levels (Collen et al. 2016). Constitutional-level and collective choice rules are easier to establish relative to operational rules, which require regular execution and monitoring. In our study, operational rules were more effectively implemented in the REDD+ user groups when compared to their non-REDD+ 
counterparts. However, this pilot program benefited from intense external inputs and monitoring. Thus, similar outcomes may be more difficult to achieve in larger scale programs.

In general, while recognizing that social change in gender and within group relations may be slow to develop, communities were able to forge equitable solutions. In addition to direct poverty reduction activities that targeted poor and marginalized households, REDD+ user groups updated membership profiles, enabling less powerful households to make claims on forest and community resources. Tole-level meetings also reduced the possibility of "elite capture." Critically, the very poor were not employed in carbon monitoring, verification, and reporting. This is because they did not possess the literacy required for technical work. This issue may require further scrutiny as REDD+ expands.

In summary, from a carbon additionality perspective, community forests sequestered around 3 tons of carbon per hectare in the pilot sites, for which communities received payments that ranged from US\$2 to 6 per ton of carbon. Households appear to be willing to accept low rents for carbon because their local institutions were strengthened and they received development assistance in the form of microcredit, grants for biogas plants and improved cook-stove installations. In a companion paper, we show that households did not, in general, bear any additional costs from REDD+, and ecological cobenefits have also begun to emerge (Sharma et al. 2015b). Thus, the proposed formula of community level development assistance, institutional strengthening, and limited household level losses seems to be working.

[1] The partners were the International Centre for Integrated Mountain Development (ICIMOD), the Federation of Community Forest User's Nepal (FECOFUN), and Asia Network for Sustainable Agriculture and Bio-resources (ANSAB).

${ }^{[2]}$ Given that REDD+ implementation has not yet started at the national level, our assessment is restricted to subnational level evidence.

${ }^{[3]}$ Forest management comprises activities such as forest fire and grazing control, establishing plant nurseries, thinning and pruning, soil erosion control, and embankment development, etc. Community Forestry Guidelines classify community forestry activities into nine main categories and stipulate different activities under each (MFSC/GON 2009).

[4] Opportunity costs are ignored because community forest conversions are not permitted. In an alternate paper, we have also shown that household level opportunity costs are limited (Sharma et al. 2015a).

[5] Although communities participated in measuring carbon sequestration, they were paid for this activity from another budget, hence this is not treated as a cost.

${ }^{[6]}$ Dalits are marginalized ethnic groups traditionally considered as untouchables.

${ }^{[7]} 1$ ton of Carbon $=3.67$ tons of $\mathrm{CO}_{2}$ (Pearson et al. 2007, as cited in ICIMOD/ANSAB/FECOFUN 2012).

${ }^{[8]}$ The carbon increments received a $16 \%$ weight by design.

${ }^{[9]}$ In REDD+ and non-REDD+ communities, $73 \%$ and $53 \%$ of the population is indigenous and $9 \%$ and $10 \%$ Dalit, respectively. The Dalit are considered to face all manners of social exclusion.
${ }^{[10]}$ The costs associated with REDD+ implementation will vary by forest type and management regime. The MRV costs may be higher in community managed forests, while the opportunity costs associated with carbon storage may be higher in government managed high-value timber forests in the Terai landscape. These costs will need to be carefully scrutinized before identifying areas for REDD+ implementation.

[11] The variation is primarily driven by the high cost of fire surveillance incurred in one of the user groups.

Responses to this article can be read online at: http://www.ecologyandsociety.org/issues/responses. $\mathrm{php} / 9370$

\section{Acknowledgments:}

This study was conducted with financial and technical support from the South Asian Network for Development and Environmental Economics (SANDEE) and International Centre for Integrated Mountain Development (ICIMOD). It benefited from additional support from the Norwegian Ministry of Foreign Affairs to the $R E D D+$ pilot program in Nepal. We thank all the community members, government, and $N G O$ representatives who participated in focus group discussions, interviews, and took the time to provide us with detailed information. We thank Erin Sills for her detailed comments and the reviewers of the Ecology and Society journal. Any remaining errors are the authors' and cannot be attributed to SANDEE, ICIMOD, or their donors.

\section{LITERATURE CITED}

Acharya, K. P., R. B. Dangi, and M. Acharya. 2011. Understanding forest degradation in Nepal. Unasylva 62(2):238.

Adhikari, B. 2009. Reduced emissions from deforestation and degradation: some issues and considerations. Journal of Forest and Livelihood 8(1):14-24.

Agrawal, A., and A. Angelsen. 2009. Using community forest management to achieve REDD+ goals. Pages 201-212 in A. Angelsen, M. Brockhaus, M. Kanninen, E. Sills, W. D. Sunderlin, and S. Wertz-Kanounnikoff, editors. Realising REDD+: national strategy and policy options. CIFOR, Bogor, Indonesia.

Angelsen, A., editor. 2008. Moving ahead with REDD: issues, options and implications. CIFOR, Bogor, Indonesia.

Angelsen, A., M. Brockhaus, M. Kanninen, E. Sills, W. D. Sunderlin, and S. Wertz-Kanounnikoff, editors. 2009. Realising REDD+: national strategy and policy options. CIFOR, Bogor, Indonesia.

Angelsen, A., M. Brockhaus, W. D. Sunderlin, L. V. Verchot, editors. 2012. Analysing REDD+: challenges and choices. CIFOR, Bogor, Indonesia.

Angelsen, A., P. Jagger. R. Babigumira, B. Belcher, N. J. Hogarth, S. Bauch, J. Börner, C. Smith-Hall, and S. Wunder. 2014. Environmental income and rural livelihoods: a globalcomparative analysis. World Development 64(S1):S12-S28. http:// dx.doi.org/10.1016/j.worlddev.2014.03.006 
Baland, J. M., P. Bardhan, and D. Mookherjee. 2010. Forests to the people: decentralization and forest degradation in the Indian Himalayas. World Development 38(11):1642-1656. http://dx.doi. org/10.1016/j.worlddev.2010.03.007

Balooni, K., and J. F. Lund. 2014. Forest rights: the hard currency of REDD+. Conservation Letters 7(3):278-284. http://dx.doi. org/10.1111/conl.12067

Bastakoti, R. R., and C. Davidsen. 2014. REDD+ and forest tenure security: concerns in Nepal's community forestry. International Journal of Sustainable Development \& World Ecology 21(2):168-180. http://dx.doi.org/10.1080/13504509.2013.879542

Brampton, J., and B. Cammaert. 2007. How can timber rents better contribute to poverty reduction through community forestry in the Terai region of Nepal? Journal of Forest and Livelihood 6(1):28-47.

Brockhaus, M., M. Di Gregorio, and R. Carmenta. $2014 a$. REDD+ policy networks: exploring actors and power structures in an emerging policy domain. Ecology and Society 19(4):29. http://dx.doi.org/10.5751/ES-07098-190429

Brockhaus, M., M. Di Gregorio, and S. Mardiah. $2014 b$. Governing the design of national REDD+: an analysis of the power of agency. Forest Policy and Economics 49:23-33. http://dx. doi.org/10.1016/j.forpol.2013.07.003

Brown, D., F. Seymour, and L. Peskett. 2008. How do we achieve REDD co-benefits and avoid doing harm? Pages 107-118 in A. Angelsen, editor. Moving ahead with REDD: issues, options and implications. CIFOR, Bogor, Indonesia.

Bushley, B. R., and D. B. Khatri. 2011. REDD+: reversing, reinforcing or reconfiguring decentralized forest governance in Nepal? Discussion Paper 11:3. Forest Action Nepal, Lalitpur, Nepal.

Central Bureau of Statistics (CBS). 2011. Nepal living standard survey. (2010/11). National Planning commission Secretariat, Government of Nepal, Kathmandu, Nepal.

Central Bureau of Statistics (CBS). 2012. National population and housing census 2011. National Planning commission Secretariat, Government of Nepal, Kathmandu, Nepal.

Chhatre, A., and A. Agrawal. 2009. Trade-offs and synergies between carbon storage and livelihood benefits from forest commons. Proceedings of the National Academy of Sciences 106 (42):17667-17670. http://dx.doi.org/10.1073/pnas.0905308106

Collen, W., T. Krause, L. Mundaca, and K. Nicholas. 2016. Building local institutions for national conservation programs: lessons for developing Reducing Emissions from Deforestation and Forest Degradation (REDD+) programs. Ecology and Society 21(2):4. http://dx.doi.org/10.5751/es-08156-210204

Community Forestry REDD+ Project Nepal (CFRPN). 2011. Operational guidelines of forest carbon trust fund 2011. CFRPN, Nepal.

Corbera, E., and H. Schroeder. 2011. Governing and implementing REDD+. Environmental Science \& Policy 14 (2):89-99. http://dx.doi.org/10.1016/j.envsci.2010.11.002
Costenbader, J. 2011. REDD+ benefit sharing: a comparative assessment of three national policy approaches. Forest Carbon Partnership/UN-REDD Programme, Geneva, Switzerland.

DANAR-Nepal. 2012. Report on assessing Dalits' involvement in REDD+ initiatives in Nepal: a case study from NORAD REDD Project (Gorkha, Chitwan and Dolakha). Dalit Alliance for Natural Resources (DANAR), Kathmandu, Nepal.

den Besten, J. W., B. Arts, and P. Verkooijen. 2014. The evolution of REDD+: an analysis of discursive-institutional dynamics. Environmental Science \& Policy 35:40-48. http://dx.doi. org/10.1016/j.envsci.2013.03.009

Dev, O. P, N. P. Yadav, O. Springate-Baginski, and J. Soussan. 2003. Impacts of community forestry on livelihoods in the Middle Hills of Nepal. Journal of Forest and Livelihood 3(1):64-77.

Dhital, N. 2009. Reducing emissions from deforestation and forest degradation (REDD) in Nepal: exploring the possibilities. Journal of Forests and Livelihoods 8(1):56-61.

Edmonds, E. V. 2002. Government-initiated community resource management and local resource extraction from Nepal's forests. Journal of Development Economics 68:89-115. http://dx.doi. org/10.1016/S0304-3878(02)00007-X

Ferraro, P. J., K. Lawlor, K. L. Mullan, and S. K. Pattanayak. 2012. Forest figures: a review of ecosystem services valuation and policy evaluation in developing countries. Review of Environmental Economics and Policy 6(1):20-44. http://dx.doi. org/10.1093/reep/rer019

Food and Agriculture Organization of the United Nations (FAO). 2011. State of the World's Forests 2011. FAO, Rome, Italy.

Food and Agriculture Organization of the United Nations (FAO). 2014. State of the World's Forest 2014. FAO, Rome, Italy.

Food and Agriculture Organization/UN Development Programme/ UN Environment Programme (FAO/UNDP/UNEP). 2008. UN collaborative programme on reducing emissions from deforestation and forest degradation in developing countries (UN-REDD). FAO, UNDP, UNEP Framework Document 20 June. FAO/UNDP/ UNEP.

Forest Resource Assessment Nepal Project/Department of Forest Research and Survey (FRA/DFRS). 2014. Terai Forests of Nepal (2010 - 2012). FRA/DFRS, Kathmandu, Nepal.

Hayes, T., and L. Persha. 2010. Nesting local forestry initiatives: revisiting community forest management in a REDD+ world. Forest Policy and Economics 12(8):545-553. http://dx.doi. org/10.1016/j.forpol.2010.07.003

International Centre for Integrated Mountain Development/Asia Network for Sustainable Agriculture and Bioresources/ Federation of Community Forest Users, Nepal (ICIMOD/ ANSAB/FECOFUN). 2012. A monitoring report on forest carbon stocks changes in REDD project sites. ICIMOD, Kathmandu, Nepal.

Iversen, V., B. Chhetry, P. Francis, M. Gurung, G. Kafle, A. Pain, and J. Seeley. 2006. High value forests, hidden economies and elite capture: evidence from forest user groups in Nepal's Terai. 
Ecological Economics 58(1):93-107. http://dx.doi.org/10.1016/j. ecolecon.2005.05.021

Kanel, K. R. 2008. So far so good: next steps in community forestry. Pages370-390 in R. Ghate, N. S. Jodha, and P. Mukhopadhyay, editors. 2008. Promise, trust and evolution: managing the commons of South Asia. Oxford University Press, Oxford, UK.

Lederer, M. 2012. REDD+ governance. WIREs Climate Change 3(1):107-113. http://dx.doi.org/10.1002/wcc. 155

Luttrell, C., L. Loft, M. F. Gebara, D. Kweka, M. Brockhaus, A. Angelsen, and W. D. Sunderlin. 2013. Who should benefit from REDD+? Rationales and realities. Ecology and Society 18(4):52. http://dx.doi.org/10.5751/es-05834-180452

Maraseni, T. N., P. R. Neupane, F. Lopez-Casero, and T. Cadman. 2014. An assessment of the impacts of the REDD+ pilot project on community forests user groups (CFUGs) and their community forests in Nepal. Journal of Environmental Management 136:37-46. http://dx.doi.org/10.1016/j.jenvman.2014.01.011

McDermott, C., and C. Ituarte-Lima. 2016. Safeguarding what and for whom? The role of institutional fit in shaping REDD+ in Mexico. Ecology and Society 21(1):9. http://dx.doi.org/10.5751/ es-08088-210109

Millennium Ecosystem Assessment (MEA). 2005. Ecosystems and human well-being: synthesis. Island, Washington, D.C., USA.

Ministry of Finance, Government of Nepal (MOF/GON). 2010. Economic survey: fiscal year 2009/10. Ministry of Finance, Government of Nepal, Kathmandu, Nepal.

Ministry of Finance, Government of Nepal (MOF/GON). 2014. Economic survey: fiscal year 2013/14. Ministry of Finance, Government of Nepal, Kathmandu, Nepal.

Ministry of Finance, Government of Nepal (MOF/GON). 2016. Economic survey: fiscal year 2015/16. Ministry of Finance, Government of Nepal, Kathmandu, Nepal.

Ministry of Forest and Soil Conservation, His Majesty's Government of Nepal (MFSC/HMGN). 2000. Forestry sector policy 2000. Ministry of Forest and Soil Conservation, His Majesty's Government of Nepal, Kathmandu, Nepal.

Ministry of Forest and Soil Conservation, Government of Nepal (MFSC/GON). 2009. Guideline for community forest development project stakeholders. Community Forests Division, Department of Forests, Government of Nepal, Kathmandu, Nepal.

Ministry of Forest and Soil Conservation, Government of Nepal (MFSC/GON). 2013. Mid term report on World Bank FCPF Grant on REDD readiness. Ministry of Forests and Soil Conservation REDD+ Forestry and Climate Change Cell, Government of Nepal, Kathmandu, Nepal.

Ministry of Forest and Soil Conservation, Government of Nepal (MFSC/GON). 2014. Nepal biodiversity strategy and action plan 2014-2020. Ministry of Forests and Soil Conservation, Government of Nepal, Kathmandu, Nepal.

Ministry of Forests and Soil Conservation/The United Nations Collaborative Programme on Reducing Emissions from Deforestation and Forest Degradation in Developing Countries/
Forest Action. (MFSC/UN-REDD/Forest Action). 2014. Understanding drivers and causes of deforestation and forest degradation in Nepal: potential policies and measures for REDD+. Discussion Paper. MFSC/UN-REDD/Forest Action, Nepal.

Miteva, D., S. K. Pattanayak, and P. J. Ferraro. 2012. Evaluation of biodiversity policy instruments: what works and what doesn't? Oxford Review of Economics and Policy. 28(2):69-92. http://dx. doi.org/10.1093/oxrep/grs009

Murdiyarso, D., M. Brockhaus, and W. D. Sunderlin, and L. Verchot. 2012. Some lessons learned from the first generation of REDD+ activities. Current Opinion in Environmental Sustainability 4(6):678-685. http://dx.doi.org/10.1016/j.cosust.2012.10.014

Nagendra, H. 2007. Drivers of reforestation in human-dominated forests. Proceedings of the National Academy of Sciences 104 (39):15218-15223. http://dx.doi.org/10.1073/pnas.0702319104

Nagendra, H., M. Karmacharya, and B. Karna. 2005. Evaluating forest management in Nepal: views across space and time. Ecology and Society 10(1):24. http://dx.doi.org/10.5751/es-01230-100124

Nepal, M., A. K. Bohara, and R. P. Berrens. 2007. The impacts of social networks and household forest conservation efforts in rural Nepal. Land Economics 83(2):174-191. http://dx.doi. org/10.3368/le.83.2.174

Nepal Foresters Association (NFA). 2011. Consolidating multistakeholder process in the forestry policy decision: scientific forest management opportunities and challenges. Ban Chautari: a multistakeholder dialogue on forest policy issues. Nepal Foresters Association, Kathmandu, Nepal.

Newton, P., B. Schaap, M. Fournier, M. Cornwall, D. W. Rosenbach, J. DeBoer, J. Whittemore, R. Stock, M. Yoders, G. Brodnig, and A. Agrawal. 2015. Community forest management and REDD+. Forest Policy and Economics 56:27-37. http://dx. doi.org/10.1016/j.forpol.2015.03.008

Pattanayak, S. K. 2009. Rough guide to impact evaluation of environmental and development programs. SANDEE Working Paper 40. South Asian Network for Development and Environmental Economics, Kathmandu, Nepal. [online] URL: http://www.sandeeonline.org/uploads/documents/

publication/847_PUB_Working_Paper_40.pdf

Pattanayak, S. K., and E. O. Sills. 2001. Do tropical forests provide natural insurance? The microeconomics of non-timber forest product collection in the Brazilian Amazon. Land Economics 77 (4):595-612. https://doi.org/10.2307/3146943 http://dx.doi. org/10.2307/3146943

Paudel, N. S., D. B. Khatri, D. R. Khanal, and R. Karki. 2013. The context of REDD+ in Nepal: drivers, agents and institutions Occasional Paper no. 81. CIFOR, Bogor, Indonesia.

Phelps, J., E. L. Webb, and A. Agrawal. 2010. Does REDD+ threaten to recentralize forest governance. Science 328:312-313. http://dx.doi.org/10.1126/science.1187774

Pokharel, R. K. 2012. Factors influencing the management regime of Nepal's community forestry. Forest Policy and Economics 17:13-17. http://dx.doi.org/10.1016/j.forpol.2011.08.002

Pokorny, B., I. Scholz, and W. de Jong. 2013. REDD+ for the poor or the poor for REDD+? About the limitations of 
environmental policies in the Amazon and the potential of achieving environmental goals through pro-poor policies. Ecology and Society 18(2):3. http://dx.doi.org/10.5751/ES-05458-180203

Poudel, M., R. Thwaites, D. Race, and G. R. Dahal. 2014. REDD+ and community forestry: implications for local communities and forest management-a case study from Nepal. International Forestry Review16(1):39-54. http://dx.doi. org/10.1505/146554814811031251

REDD Forestry and Climate Change Cell, Ministry of Forests and Soil Conservations (RFCCC/MSFC). 2013. Mid-term Report. The World Bank, FCPF grant on REDD Readiness. REDD Forestry and Climate Change Cell, Ministry of Forests and Soil Conservations, Government of Nepal.

REDD Implementation Centre, Ministry of Forests and Soil Conservation (RIC/MFSC). 2015. Nepal REDD+ Strategy. REDD Implementation Centre, Ministry of Forests and Soil Conservation, Government of Nepal, Kathmandu, Nepal.

Rendón Thompson, O., J. Paavola, J. R. Healey, J. P. G. Jones, T. R. Baker, and J. Torres. 2013. Reducing emissions from deforestation and forest degradation (REDD+): transaction costs of six Peruvian projects. Ecology and Society 18(1):17. http://dx. doi.org/10.5751/es-05239-180117

Rights and Resources Initiative (RRI). 2014. What future for reform? Progress and slowdown in forest tenure reform since 2002. RRI, Washington, D.C., USA. [online] URL: http:// rightsandresources.org/wp-content/uploads/RRI4011D FlagshipMAR2014r13B.pdf

Schroeder, H., and C. McDermott. 2014. Beyond carbon: enabling justice and equity in REDD+ across levels of governance. Ecology and Society 19(1):31. http://dx.doi. org/10.5751/ES-06537-190131

Seymour, F., T. La Vina, and K. Hite. 2014. Evidence linking community-level tenure and forest condition: an annotated bibliography. Climate and Land Use Alliance, San Francisco, California, USA. http://www.climateandlandusealliance.org/wpcontent/uploads/2015/08/Community_level tenure and forest_condition bibliography.pdf

Sharma, B. P., S. Pattanayak, M. Nepal, P. Shyamsundar, and B. S. Karky. 2015b. REDD+ impacts: evidence from Nepal. SANDEE Working Paper No. 95-15. South Asian Network for Development and Environmental Economics, Kathmandu, Nepal. [online] URL: http://www.sandeeonline.org/uploads/ documents/publication/1064 PUB Working Paper 95 Bishnu et al. pdf

Sharma, B. P., P. Shyamsundar, M. Nepal, S Pattanayak, and B. S. Karky. 2015a. Are community forestry institutions appropriate for implementing REDD+? Lessons from Nepal. SANDEE Working Paper 94-15. South Asian Network for Development and Environmental Economics, Kathmandu, Nepal. http://lib. icimod.org/record/32237/files/sandeePUB Working Paper 94.pdf

Shrestha, S., B. S. Karky, and S. Karki. 2014. Case study report: REDD+ pilot project in community forests in three watersheds of Nepal. Forests 5:2425-2439. http://dx.doi.org/10.3390/ f5102425
Shyamsundar, P., and R. Ghate. 2014. Rights, rewards, and resources: lessons from community forestry in South Asia. Review of Environmental Economics and Policy 8(1):80-102. http://dx.doi. org/10.1093/reep/ret022

Sills, E. O., C. de Sassi, P. Jagger, K. Lawlor, D. A. Miteva, S. K. Pattanayak, and W. D. Sunderlin. 2017. Building the evidence base for REDD+: study design and methods for evaluating the impacts of conservation interventions on local well-being. Global Environmental Change. 43:148-160. http://dx.doi.org/10.1016/j. gloenvcha.2017.02.002

Smith, J., and S. J. Scherr. 2003. Capturing the value of forest carbon for local livelihoods. World Development 31 (12):2143-2160. http://dx.doi.org/10.1016/j.worlddev.2003.06.011

Somanathan, E., R. Prabhakar, and B. S. Mehta. 2009. Decentralization for cost-effective conservation. Proceedings of the National Academy of Sciences 106(11):4143-4147. http://dx. doi.org/10.1073/pnas.0810049106

Springate-Baginski, O., and E. Wollenberg, editors. 2010. REDD, forest governance and rural livelihoods: the emerging agenda. CIFOR, Bogor, Indonesia.

Springate-Baginski, O., N. Yadav, O. P. Dev, and J. Soussan. 2003. Institutional development of forest user groups in Nepal: processes and indicators. Journal of Forest and Livelihood 3 (1):21-36.

Sunderlin, W. D., A. M. Larson, A. Duchelle, E. O. Sills, C. Luttrell, P. Jagger, S. Pattanayak, P. Cronkleton, and A. D. Ekaputri. 2010. Technical guidelines for research on REDD+ project sites. CIFOR, Bogor, Indonesia.

Tachibana, T., and S. Adhikari. 2009. Does community-based management improve natural resource condition? Evidence from the forests in Nepal. Land Economics 85(1):107-131. http://dx.doi. org/10.3368/le.85.1.107

United Nations Framework Conventions on Climate Change (UNFCCC). 2015. Adoption of the Paris Agreement: proposal by the President: Draft decision -/CP.21 UNFCCC, Paris, France. [online] URL: http://unfccc.int/resource/docs/2015/cop21/eng/ 109r01.pdf

Visseren-Hamakers, I. J., A. Gupta, M. Herolds, M. Peña-Claros, and M. J. Vijge. 2012. Will REDD+ work? The need for interdisciplinary research to address key challenges. Current Opinion in Environmental Sustainability 4:590-596 http://dx.doi. org/10.1016/j.cosust.2012.10.006

Wertz-Kanounnikoff, S., and D. McNeill. 2012. Performance indicators and REDD+ implementation. Pages 233-246 in A. Angelsen, M. Brockhaus, W. D. Sunderline, and L. V. Verchot, editors. Analysing REDD+: challenges and choices. CIFOR, Bogor, Indonesia.

Wilcove, D. S., and L. P. Koh. 2010. Addressing the threats to biodiversity from oil-palm agriculture. Biodiversity and Conservation 19(4):999-1007. http://dx.doi.org/10.1007/s10531-009-9760$\underline{x}$

World Bank. 2009. Roots for good forest outcomes: an analytical framework for governance reforms. Report No. 49572-GLB. World Bank, Washington, D.C., USA. 
World Bank. 2013. World development indicators 2013. World Bank, Washington, D.C., USA. http://dx.doi.org/10.1596/978-0$\underline{-8213-9824-1}$

World Bank. 2016. Forest action plan FY16-20. World Bank Group, Washington, D.C., USA. [online] URL: http:// documents.worldbank.org/curated/en/240231467291388831/Forestaction-plan-FY16-20 